\title{
Preemption of compliance costs and the voluntary adoption of SFAS no. $123(\mathrm{R})$
}

\author{
Ahmed M. Ebrahim \\ Fairfield University, aebrahim@fairfield.edu \\ Bruce M. Bradford \\ Fairfield University, bbradford@fairfield.edu
}

Follow this and additional works at: https://digitalcommons.fairfield.edu/business-facultypubs Copyright 2014 Emerald Group

This article is (c) Emerald Group Publishing and permission has been granted for this version to appear here. Emerald does not grant permission for this article to be further copied/distributed or hosted elsewhere without the express permission from Emerald Group Publishing Limited.

\section{Peer Reviewed}

\section{Repository Citation}

Ebrahim, Ahmed M. and Bradford, Bruce M., "Preemption of compliance costs and the voluntary adoption of SFAS no. 123 (R)" (2014). Business Faculty Publications. 150.

https://digitalcommons.fairfield.edu/business-facultypubs/150

\section{Published Citation}

Ebrahim, Ahmed, and Bruce Bradford. "Preemption of compliance costs and the voluntary adoption of SFAS no. 123 (R)." Journal of Financial Reporting and Accounting 12, no. 1 (2014): 1-1.

This item has been accepted for inclusion in DigitalCommons@Fairfield by an authorized administrator of DigitalCommons@Fairfield. It is brought to you by DigitalCommons@Fairfield with permission from the rightsholder(s) and is protected by copyright and/or related rights. You are free to use this item in any way that is permitted by the copyright and related rights legislation that applies to your use. For other uses, you need to obtain permission from the rights-holder(s) directly, unless additional rights are indicated by a Creative Commons license in the record and/or on the work itself. For more information, please contact digitalcommons@fairfield.edu. 


\title{
Preemption of Compliance Costs and the Voluntary Adoption of SFAS No. 123(R)
}

\author{
Ahmed Ebrahim \\ Assistant Professor of Accounting \\ Dolan School of Business \\ Fairfield University \\ Bruce Bradford \\ Associate Professor of Accounting \\ Dolan School of Business \\ Fairfield University
}

\begin{abstract}
Purpose - The paper studies a preemption proposition for the compliance costs associated with stock option expensing under SFAS 123(R) by examining whether early adopters used their discretion over option pricing model inputs to mitigate the adoption effect.

Design/methodology/approach - The paper uses a matched sample approach of firms that voluntarily adopted stock option expensing during the 2002-2004 period and similar firms that waited until the mandatory expensing. The paper empirically examines some determinants of voluntary adoption, and the changes in option pricing model inputs during the period leading to mandatory expensing.

Findings - The paper reports evidence that voluntary adopters of stock option expensing during the 2002-2004 period have used the period leading to mandatory expensing to preempt its compliance cost effect. They exercised their discretion by decreasing estimates for stock price volatility and time-to-maturity to preempt or minimize the reduction in earnings before mandatory adoption date.

Originality/value - Results of this paper are useful to accounting regulators in understanding the reaction of financial statement preparers to deliberations and effective dates of accounting standards setting process.
\end{abstract}

Keywords: Accounting, stock options, pricing model, voluntary adoption, preemption

Paper Classifications - Research paper 


\section{INTRODUCTION}

Accounting for employee stock options has been one of the most challenging and controversial issues the accounting profession has faced. The Financial Accounting Standards Board (FASB) added this issue to its agenda in 1984. Under APB 25, the original requirements for accounting for employee stock options used the intrinsic value method of accounting. Following these requirements, firms generally recognized compensation expense on the stock options grant date only if the quoted market price of the stock is higher than the amount an employee must pay to acquire the stock.

On June 1993, FASB issued a highly controversial Exposure Draft, “Accounting for Stock-Based Compensation" which proposed a fair value method for the valuation of granted stock options through the use of well recognized option pricing models. The estimated value of employee stock options would become part of recognized compensation expense and reported on the face of the income statement. After coming under an enormous pressure from different constituencies, including Congress, the FASB compromised on this issue. In 1995, the FASB issued SFAS 123 “Accounting for Stock-Based Compensation". It allowed firms to continue using the intrinsic value method with disclosure of the pro forma stock option expense under the fair value method.

Virtually all of the Fortune 500 firms, except Boeing and Winn Dixie, initially opted to continue using the intrinsic value method (Robinson and Burton 2004; Fredrickson et al. 2006). Following the accounting scandals of Enron and WorldCom, the U.S. Congress began demanding greater transparency in financial reporting and greater accountability of top management culminating in the Sarbanes-Oxley Act of 2002. In response to this new political environment, some firms announced they would voluntarily adopt fair value accounting for stock options. Ultimately, the FASB revisited this issue and revised SFAS 123. They issued SFAS 123(R) in December 2004 
which required firms to recognize fair value of stock options as an expense effective from fiscal years beginning after June 15, 2005.

In anticipation of the enacting of mandatory stock option expensing late 2004, many companies preemptively decided to adopt the expensing of employee stock options during 2003 and early 2004 before the issuance of SFAS 123(R) and its effective date. Some of the determining factors of such preemptive adoption can be attributed to investors' perceptions and the anticipated cost of compliance with stock option mandatory expensing which seemed inevitable to many financial statement preparers during 2003 and early 2004 (Langer and Lev 1993). On one hand, those voluntary adopting firms can get the benefit of being perceived by the market as firms with greater transparency and higher quality corporate governance (Deshmukh et al. 2006). On the other hand, adopting SFAS 123(R) also involved recognizing significant additional compensation expense based on the Black-Scholes option pricing model (Botosan and Plumlee 2001). Schroeder and Schauer (2008) reported that the expensing of stock options under SFAS 123(R) had a material impact on firms' net income. Because the choice of inputs to the pricing model results in a wide range of possible estimated stock option fair values and recognized compensation expense (Coller and Higgs 1997), management might be inclined to use its discretion over these estimated inputs to preempt the compliance cost and minimize the effect of stock option expensing on their financial statements (Hirst et al. 2005).

The main objective of this paper is to examine and detect any preemption behavior by firms voluntarily choosing to expense employee stock options during the $2002-2004$ period by using their discretion over some estimated inputs to the stock option pricing model to mitigate the effect of stock option expensing during the period leading to the mandatory expensing effective date. We propose the preemption hypothesis in which management is motivated to use its 
discretion to reduce compliance costs associated with the adoption of this income reducing accounting change. In the case of voluntary adoption of SFAS 123(R), we examine whether or not managers use discretion over the four estimated inputs to the Black-Scholes option pricing model to reduce the amount of compensation expense recognized on the income statement. This paper expands the literature on compliance costs associated with the voluntary adoption of SFAS 123(R). We examine the period before and after the voluntary adoption wave of $2002-2004$ for evidence that management used its discretion to manage any of the four disclosed Black-Scholes model inputs, and examine any evidence of systematic change in these model inputs in the direction that would minimize the fair value of stock options and compensation expense.

The remaining of the paper is organized as follows. The next section reviews the literature on incentives for voluntary adoption of accounting changes. The third section describes the preemption concept and develops the hypotheses. The fourth section describes the data and empirical methods. The fifth section presents and discusses our results. The final section concludes the paper.

\section{INCENTIVES FOR VOLUNTARY ADOPTION}

The accounting literature has proposed numerous incentives for adopting accounting changes voluntarily prior to their mandatory effective dates. Following (Langer and Lev 1993), we classify these incentives for voluntary adoption into investor perception or compliance costs. Investor perception involves management attempts to change investor's expectations. (Amir and Ziv 1997a, b) develop a model of voluntary adoption for SFAS 106 and suggested that firms adopt changes in accounting regulation early if the effects are favorable. They assume that voluntary adoption is a means by which management can signal its private information about the effects of this change on the future prospects of the firm. Consistent with this model, firms 
demonstrating earnings increases in association with the accounting changes are more likely to be early adopters (Balsam et al. 1995; Langer and Lev 1993; Sami and Welsh 1992). Both Amir and Livnat (1996) and Balsam et al. (1995) report that favorable liability changes may also provide creditable signals for voluntary adopters.

Consistent with the investor perception incentive, the market has closely followed FASB's deliberations on stock-based compensation accounting. Significant abnormal returns have been documented around the release of the Exposure Draft in June 1993 and the release of SFAS 123 in October 1995 (Espahbodi et al. 2002; Dechow et al. 1996). Aboody et al. (2004) finds the degree of information asymmetry to be greater among voluntary adopters of SFAS 123(R). Robinson and Burton (2004) observed a cumulative abnormal return of 0.53 percent (significant at the 0.05 level) for voluntary adopters of SFAS 123(R) over a three day event window (days -1 to 1$)$.

On the issue of recognition versus disclosure, the market reaction to FASB's Exposure Draft and subsequent deliberations strongly suggests that "disclosure is no substitute for recognition" (Esphahbodi et al. 2002). Davis-Friday et al. (2004) investigated disclosures associated with retiree benefits under SFAS 106 and found disclosures to be less reliable than recognition of post-retirement benefit liabilities or for pension liabilities. Frederickson et al. (2006) found decision makers interpreted income statements with mandated recognition of stock option expense as more reliable than voluntary recognition or voluntary disclosure. Viger et al. (2008) examined the credit decision of bank loan officers and found that loan officers failed to incorporate the information from the voluntary disclosure in their analysis ${ }^{1}$. Loan officers assigned higher risk to firms reporting lower income due to stock option expense recognition and

\footnotetext{
${ }^{1}$ In a similar study, (Ahmed et al 2006) examined the valuation of common stock of banks. Some of the banks recognized the value of portfolios of traded stock options under SFAS 133 while others disclosed these values. Recognition of derivative values resulted in significantly different valuations from controls.
} 
were less willing to grant them the requested loan. Niu and Xu (2009) reported evidence that expensing stock options - compared with the pro forma disclosure- increases the perceived quality of firm's financial reporting and has some incremental effect on the market value of the firm.

The second category of incentives for voluntary adoption is compliance costs (Langer and Lev 1993). Watts and Zimmerman (1978) proposed that larger firms were more likely to be voluntary adopters of income decreasing changes because they can absorb information production costs associated with the accounting change. Smaller firms are more likely to be voluntary adopters of income increasing accounting changes. Sami and Welsh (1992) provide empirical support for compliance costs being a consideration in the voluntary adoption of SFAS 87 . They found that big companies with large and fully funded pension plans were more likely to early adopt SFAS 87. Holthausen and Leftwich (1983) reviewed the accounting change literature and concluded that both size and leverage were important proxies for compliance costs. Size is a proxy for political visibility and leverage is a proxy for contracting and monitoring costs. With respect to the issue of stock compensation expense, Aboody et al. (2004) found that voluntary adopters of SFAS 123(R) were significantly larger than control firms.

Early adoption of mandatory accounting changes has been found to follow some adoption pattern for several mandatory accounting changes (Balsam et al. 1995). Companies tended to adopt equity-increasing changes early. Equity-decreasing changes were adopted based on how such changes would affect their reported earnings and return on assets. In the case of pension accounting for example, Tung and Weygandt (1994) reported that most of the firms that adopted SFAS 87 early had a positive effect on reported earnings. Early adopters were also more likely to have higher leverage and lower interest coverage ratio before the adoption. They concluded that 
managers used early adoption to relax debt covenants. Both Gujarathi and Hoskin (1992) and Simon and Costigan (1996) found that early adoption of SFAS 96 was more likely when it resulted in increased earnings. Amir and Livnat (1996) also reported that early adopters of SFAS 106 chose to recognize the income reducing cumulative effect of post-retirement benefits in the year of the adoption (big bath) rather than prorate it over a number of years.

Management has also taken action to minimize the exercise price of stock options by selecting a favorable grant date. Under the intrinsic value method, the market value of common stock on the grant date becomes the exercise price for stock options. Yarmack (1997) and Aboody and Kasznik (2000) document that managers tend to time the stock option grants so they occur before the release of favorable information or after the release of unfavorable information. Lie (2005) finds negative abnormal returns prior to the grant and positive abnormal returns after it. Chauvin and Shenoy (2001) also demonstrate stock price decreases in the period immediately before the grant date.

Under SFRS 123(R), the fair value of stock options are generally determined using the BlackScholes model based on four estimated inputs: risk-free interest rate, time-to-maturity, stock price volatility, and dividend yield (Grinblatt and Titman 2002). It is widely recognized that different methods of estimating the Black-Scholes model inputs could lead to large and significant differences in compensation expense (Coller and Higgs 1997), and that stock option pricing is most sensitive to changes in factors that affect stock price or stock price volatility (Core and Guay 2002).

Results of the empirical analysis of management's discretion in estimating option pricing model inputs have been mixed. Balsam et al. (2003) found no support for the use of Black-Scholes 
model inputs to manage stock option expense disclosed under SFAS 123. Robinson and Burton (2004) found dividend yield significantly higher and stock price volatility significantly lower in voluntary adopters of SFAS 123(R) as compared to control firms. Aboody et al. (2006) calculate fair value of stock options by strict application of the provisions recommended in SFAS 123(R) and find that managers systematically understate compensation expense. Bartov et al. (2007) focus on stock price volatility and argue that management uses its discretion in estimating stock price volatility to understate compensation expense. Johnston (2006) collected the disclosed Black-Scholes model inputs for a sample of voluntary adopters and control firms, and found that voluntary adopters managed compensation expense downward. However, in a similar study, Hodder et al. (2006) found that voluntary adopters reported higher fair values and compensation expense than control firms.

Prior empirical research on the voluntary adoption of stock option expensing has focused on management's use of its discretion in estimating the option pricing model inputs in the year of the voluntary adoption and/or the year prior to it. In this paper, we introduce the preemption hypothesis and examine the voluntary adoption as part of a preemption effort to mitigate the effect of mandatory expensing by exercising management's discretion over the option pricing model inputs during the years leading to the mandatory expensing effective date. The paper tracks management choices of option pricing model inputs before the year of voluntary adoption through the mandatory expensing year to examine whether firms used the period leading to mandatory expensing as a preemption period to smooth out the effect of mandatory expensing on their financial statements.

\section{THE PREEMPTION INCENTIVE FOR VOLUNTARY ADOPTION}

Prior literature suggests that firms may use the voluntary adoption and the transition period before the mandatory effective date to mitigate adverse effects of the new accounting rules on 
their financial statements. In other words, firms may use the voluntary adoption as a preemption tool to set the stage for the mandatory adoption and manage the initial effect of this accounting change. One of the criticisms of SFAS 123(R) was that the Standard's Exposure Draft provided managers with the opportunity to manipulate fair value estimates to preempt the effect of recognizing stock option expense (Hirst et al. 2005). Prior empirical research has shown that management used its discretion to underestimate option fair value (Aboody et al. 2006), and that was especially true with regard to the stock price volatility estimates (Bartov et al. 2007).

Because it was commonly recognized during 2003 and early 2004 that mandatory expensing of stock options is inevitable, we expect that firms voluntarily adopting to expense their stock options may use the adoption decision as part of a preemption effort to smooth out the effect of the expected mandatory expensing during the voluntary adoption year and the years leading to that mandatory expensing compared with the year(s) prior to the voluntary adoption. Therefore, the paper examines the following two null hypotheses:

$\mathrm{Ho}_{1}$ : Managers do not use their discretion to minimize pro forma stock option expense disclosed under SFAS 123.

Ho2: Managers do not use their discretion to minimize stock option compensation expense after their voluntary adoption of SFAS 123(R).

\section{DATA AND METHOD}

Our study includes 215 companies that announced voluntary adoption of SFAS 123(R) during the years 2002 - 2004. Sample firms were initially identified using a list of 576 firms that announced their voluntary adoption of stock option expensing during the 2002-2004 period which was published by the former Bear Stearns. The final study sample includes only the public firms with the required financial data and the disclosed inputs to the stock option pricing model available in their annual reports for the study periods. Control firms were chosen as a matching 
sample for expensing firms to control for any real economic effects on the adoption decision (Cohen et al. 2008). Control firms were identified from the same four-digit SIC code industry. Each control firm granted employee stock options every year between 2001 and 2007, and continued to follow the pro forma disclosure for employee stock option expense until the mandatory effective date of SFAS 123(R). This helps to avoid any measurement or classification errors resulting from any late voluntary adoption of stock option expensing.

Table 1 summarizes voluntary adopters by year and two-digit SIC industry code. Voluntary adopters are clustered both by year and by industry. Eighty percent (171 of 215) of the voluntary adoptions in the study sample occurred in 2003. The timing of the voluntary adoptions suggests management might be responding to the political environment in the wake of the Enron and WorldCom scandals by taking actions to demonstrate higher quality corporate governance by voluntarily increasing the transparency of their financial statements (Deshmukh et al. 2006). Voluntary adoption announcements are also clustered in the financial services sector (SIC 60 69) during 2002 and 2003, which suggests that this sector of the economy might have more to gain from increased financial reporting transparency. 
Table 1. Voluntary Adopters of SFAS 123(R) by SIC Code and Year of Adoption

\begin{tabular}{|c|c|c|c|c|}
\hline SIC Code & Description & 2002 & 2003 & 2004 \\
\hline 13 & OIL AND GAS EXTRACTION & 1 & 4 & 0 \\
\hline 20 & FOOD AND KINDRED PRODUCTS & 1 & 4 & 0 \\
\hline 23 & APPAREL AND OTHER TEXTILE PRODUCTS & 0 & 1 & 0 \\
\hline 24 & LUMBER AND WOOD PRODUCTS & 1 & 1 & 0 \\
\hline 25 & FURNITURE AND FIXTURES & 0 & 2 & 0 \\
\hline 27 & PRINTING AND PUBLISHING & 0 & 2 & 1 \\
\hline 28 & CHEMICALS AND ALLIED PRODUCTS & 0 & 11 & 1 \\
\hline 29 & PETROLEUM AND COAL PRODUCTS & 0 & 3 & 0 \\
\hline 30 & RUBBER AND MISC. PLASTICS PRODUCTS & 1 & 0 & 0 \\
\hline 33 & PRIMARY METALS INDUSTRIES & 0 & 1 & 0 \\
\hline 34 & FABRICATED METAL PRODUCTS & 0 & 2 & 0 \\
\hline 35 & INDUSTRIAL MACHINERY AND EQUIPMENT & 0 & 4 & 0 \\
\hline 36 & ELECTRONIC \& OTHER ELECTRIC EQUIPMENT & 1 & 4 & 0 \\
\hline 37 & TRANSPORTATION EQUIPMENT & 0 & 4 & 0 \\
\hline 38 & INSTRUMENTS AND RELATED PRODUCTS & 0 & 1 & 0 \\
\hline 39 & MISCELLANEOUS MANUFACTURING INDUSTRIES & 0 & 3 & 0 \\
\hline 42 & TRUCKING AND WAREHOUSING & 0 & 2 & 1 \\
\hline 45 & TRANSPORTATION BY AIR & 0 & 1 & 0 \\
\hline 48 & COMMUNICATIONS & 3 & 3 & 0 \\
\hline 49 & ELECTRIC, GAS, AND SANITARY SERVICES & 1 & 6 & 0 \\
\hline 50 & WHOLESALE TRADE - DURABLE GOODS & 0 & 4 & 0 \\
\hline 51 & WHOLESALE TRADE - NONDURABLE GOODS & 1 & 2 & 0 \\
\hline 52 & BUILDING MATERIALS \& GARDEN SUPPLIES & 0 & 2 & 0 \\
\hline 53 & GENERAL MERCHANDISE STORES & 0 & 3 & 0 \\
\hline 54 & FOOD STORES & 0 & 1 & 0 \\
\hline 58 & EATING AND DRINKING PLACES & 1 & 1 & 0 \\
\hline 59 & MISCELLANEOUS RETAIL & 1 & 3 & 1 \\
\hline 60 & DEPOSITORY INSTITUTIONS & 12 & 33 & 4 \\
\hline 61 & NONDEPOSITORY INSTITUTIONS & 0 & 3 & 0 \\
\hline 62 & SECURITY AND COMMODITY BROKERS & 0 & 5 & 0 \\
\hline 63 & INSURANCE CARRIERS & 3 & 24 & 0 \\
\hline 64 & INSURANCE AGENTS, BROKERS, \& SERVICE & 0 & 1 & 0 \\
\hline 65 & REAL ESTATE & 1 & 0 & 0 \\
\hline 67 & HOLDING AND OTHER INVESTMENT OFFICES & 7 & 17 & 0 \\
\hline 70 & HOTELS AND OTHER LODGING PLACES & 0 & 1 & 0 \\
\hline 72 & PERSONAL SERVICES & 0 & 0 & 1 \\
\hline 73 & BUSINESS SERVICES & 0 & 5 & 1 \\
\hline 78 & MOTION PICTURES & 0 & 2 & 0 \\
\hline 79 & AMUSEMENT \& RECREATION SERVICES & 0 & 1 & 0 \\
\hline 80 & HEALTH SERVICES & 2 & 2 & 0 \\
\hline 87 & ENGINEERING \& MANAGEMENT SERVICES & 0 & 2 & 0 \\
\hline Total & & 37 & 171 & 10 \\
\hline
\end{tabular}


Table 2 summarizes basic descriptive statistics of both voluntary adopters and control firms. The Black-Scholes model inputs (risk-free interest rate, stock price volatility, time-to-maturity, and dividend yield) used by managers to estimate fair value of stock options were hand-gathered from the 10-K footnote disclosures for years 2001 through 2007 for both sample and control firms. To control for exogenous factors in this study, five control variables are used: size, bookto-market ratio, return on assets, debt-to-assets ratio, and financial need (Dechow et al. 1996; Balsam et al. 1995).

Univariate analysis of these nine variables consists of examining the mean differences between the voluntary adopters and control firms by year and in total. The control variables were drawn from Research Insight (North American). Size is measured using the natural log of the market value of equity (MKVAL). Book-to-market ratio is the book value of equity (CEQ) divided by the market value of equity. Return on assets is determined as income before extraordinary items available to common stocks (IBCOM) divided by total assets (AT) and expressed as a percentage. Debt-to-asset ratio is determined as total liabilities (DT) divided by total assets and expressed as a percentage. Financial need is free cash flow divided by total assets. Free cash flow is determined as operating activities-net cash flow (OANCF) less total dividends (DV) less capital expenditure (CAPX) where these items were all drawn from the statement of cash flows. 
Table 2. Descriptive Statistics

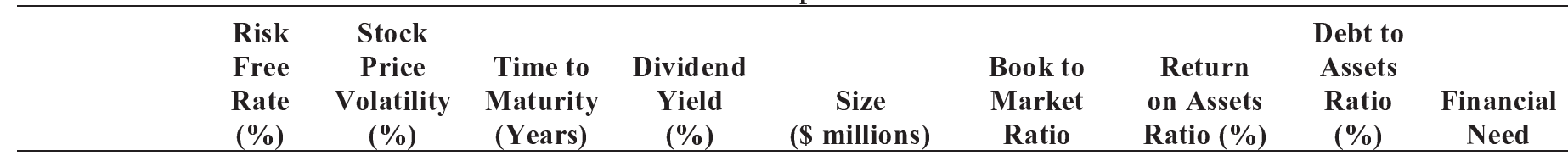

Panel A: Early Adopters (all years):

$\begin{array}{lrrrrrrrrr}\text { Mean } & 4.33 & 36.96 & 5.7 & 2.32 & 17,849.66 & 0.38 & 1.15 & 28.03 & (0.12) \\ \text { Median } & 4.39 & 30.00 & 5.5 & 1.50 & 2,737.65 & 0.45 & 2.34 & 23.31 & 0.02 \\ \text { Std. Dev. } & 1.05 & 25.14 & 1.9 & 12.81 & 45,634.74 & 2.43 & 21.44 & 23.75 & 19.08 \\ \text { Minimum } & 0.96 & 0.00 & 0.0 & 0.00 & 0.00 & (63.71) & (459.98) & 0.00 & (394.08) \\ \text { Maximum } & 9.50 & 350.00 & 12.0 & 482.00 & 475,003.00 & 5.69 & 65.36 & 136.97 & 260.71\end{array}$

Panel B: Control Firms (all years):

\begin{tabular}{lrrrrrrrrr} 
Mean & 4.29 & 43.51 & 5.5 & 1.10 & $2,010.14$ & $(0.41)$ & $(0.93)$ & 20.85 & 0.00 \\
Median & 4.30 & 37.46 & 5.0 & 0.00 & 381.60 & 0.46 & 2.08 & 12.17 & 0.02 \\
Std. Dev. & 1.10 & 25.16 & 1.8 & 8.31 & $5,702.18$ & 34.03 & 23.04 & 23.98 & 0.20 \\
Minimum & 0.98 & 0.00 & 0.0 & 0.00 & 0.68 & $(1,262.57)$ & $(292.74)$ & 0.00 & $(1.66)$ \\
Maximum & 6.80 & 165.00 & 10.0 & 312.00 & $67,458.70$ & 4.59 & 41.72 & 213.41 & 1.46 \\
\hline
\end{tabular}

Variable definitions:

Risk-free rate

Stock price volatility

Time-to-maturity

Dividend yield

Size

Book to market ratio

Return on assets

Debt to assets ratio

Financial need
$=$ Manager's estimate of the risk-free rate of interest disclosed in the footnotes of the financial statements.

$=$ Manager's estimate of the stock price volatility disclosed in the footnotes of the financial statements.

= Manager's estimate of the time-to-maturity disclosed in the footnotes of the financial statements.

$=$ Manager's estimate of the dividend yield disclosed in the footnotes of the financial statements.

$=$ Natural log of the market value of equity.

$=$ Book value of equity divided by the market value of equity.

$=$ Income before extraordinary items available to common shareholders divided by total assets.

$=$ Total liabilities divided by total assets.

$=$ Free cash flow divided by total assets.

Two multivariate analyses are conducted. To examine questions about preemption of potential compliance costs, we develop a cross-sectional logistic regression model (equation 1) based on the four Black-Scholes model inputs and tracks these estimates year by year for the period between 2000 and 2007 which included years prior to and subsequent to the voluntary adoption year as well as the voluntary adoption year itself. Our second analysis develops a logistic regression (equation 2) that includes other control variables that might affect the company's decision of voluntary adoption. The role of political costs in the decision to adopt is captured 
with size and debt to assets ratio. The remaining control variables describe the financial condition of the firm which may have had a role in facilitating or restricting the decision to adopt.

To test the two hypotheses for manager's attempt to preempt the effects of SFAS 123(R) stock option expense, we examine equation (1) for each year from $2000-2007$ separately and for all years combined. Significant negative coefficients for VOL, RF, or LIFE will be consistent with managers changing their estimates in a direction that will minimize the fair value of stock options and the related compensation expense. A significant positive coefficient for DIV has the same effect (see Grinblatt and Titman 2002). We estimate the following logistic regression model:

$$
A D O P T_{i t}=\alpha+\beta_{1} V O L_{i t}+\beta_{2} R F_{i t}+\beta_{3} L I F E_{i t}+\beta_{4} D I V_{i t}
$$

Where,
ADOPT $=$ is a dichotomous variable set to 1 if the company is classified as a voluntary adopter which recognized SFAS 123(R) stock option expense in the period 2002-2004, 0 otherwise.
VOL = Management's estimate of stock price volatility as disclosed in the footnotes of the financial statements.
RF = Management's estimate of the risk-free interest rate as disclosed in the footnotes of the financial statements.
LIFE = Management's estimate of the average time-to-maturity for outstanding stock option grants as disclosed in the footnotes of the financial statements.
DIV = Management's estimate of dividend yield as disclosed in the footnotes of the financial statements.

Second, we develop a logistic regression model using Black-Scholes model inputs and a set of control variables. This model is applied to the year of adoption for voluntary adopters and their pair-matched controls. A backwards stepwise elimination is used to develop a parsimonious model in order to determine which variables are most important to the voluntary adoption 
decision. The following model (2) also provides evidence to whether political costs are important

to the decision to adopt SFAS 123(R) early.

$A D O P T_{i t}=\alpha+\beta_{1} V O L_{i t}+\beta_{2} R F_{i t}+\beta_{3} L I F E_{i t}+\beta_{4} D I V_{i t}+\beta_{5} S i z e+\beta_{6} B M+\beta_{7} D A+\beta_{8} R O A+\beta_{9} F N$

Where,

Size $=$ Natural log of the market value of equity.

$\mathrm{BM}=$ Book to market ratio determined as the book value of equity divided by the market value of equity.

$\mathrm{DA}=$ Debt to asset ratio determined as total liabilities divided by total assets.

ROA $=$ Return on assets determined as income before extraordinary items available to common shareholders divided by total assets.

$\mathrm{FN}=$ Financial need determined as the free cash flow divided by total assets.

ADOPT, VOL, RF, LIFE, and DIV are the same as for equation (1).

Dechow et al (1996) have used size, book-to-market ratio, leverage, and free cash flow as control variables. Since Watts and Zimmerman (1978) argued that the size of the firm affects the political cost of its accounting choices, many papers that examined different accounting choices have controlled for firm size including recent papers like Jones (2011). Schroeder and Schauer (2008) reported that the impact of stock option expensing on firm's net income was a function of firm size. Many of prior papers (such as Jeter et al 2008) use the natural logarithm of firm's equity as a proxy for firm size. Robinson and Burton (2004) have also defined size as the natural $\log$ of market value of equity and referred to this measure of size as a proxy for political costs. Jeter et al (2008) has also controlled for the leverage level of the firm measured by the ratio of its total liabilities to total assets. In addition, Krishnan et al (2008) have controlled for profitability measured by ROA which was preferred by Lie (2001) over the EPS as a profitability measure. Gul (2001) has reported that managers in firms with high free cash flows are more likely to adopt income-increasing accounting choices to increase their compensation.

The coefficients for Size, BM and ROA are expected to be significantly positive. We anticipate that larger firms with higher market values and earnings are more likely to recognize stock 
option expense because they are more able to absorb the effects of this income decreasing accounting change. The coefficients for DA and FN are expected to be significantly negative since firms with a heavier debt burden or higher free cash flows are less likely to be willing to recognize an additional expense.

\section{RESULTS AND DISCUSSION}

The main results are summarized in Tables $3-5$. Table 3 summarizes mean differences for the four main inputs of the Black-Scholes option valuation model and five additional control variables. Table 4 summarizes the year by year logistic regression of equation (1) from 2000 through 2007. Table 5 summarizes regression results for equation (2) for the adoption year and presents a parsimonious model of variables related to the decision to recognize stock option expense.

Examining the differences in means (Table 3) between the adoption and control firms over the period demonstrates several interesting patterns. Grinblatt and Titman (2002) and Bartov et al. (2007) suggest that stock price volatility is the Black-Scholes model input over which managers have the greatest discretion. If managers were to preempt the effects of recognizing stock option expense by adjusting their estimates of inputs to the option pricing model, it should be detectible through a systematic reduction of the stock price volatility estimate.

Table 3 shows that the expected stock price volatility for the voluntary adoption firms was not significantly different from the volatility for control firms during the period from $2000-2003$. Beginning in 2004, stock price volatility of voluntary adopters decreased each year. However, stock price volatility of the control firms remained about the same throughout the period. This suggests that managers did not use their discretion over estimated stock price volatility to reduce 
the pro forma stock option expense. Beginning with the issuance of SFAS 123(R), managers of voluntary adoption firms did take positive action to reduce the recognized stock option expense.

Grinblatt and Titman (2002) suggest that managers have less discretion in the Black-Scholes model estimates for dividend yield and time-to-maturity. However, Table 3 demonstrates that estimates of time-to-maturity for voluntary adopters became consistently shorter after issuance of SFAS 123(R). This result is consistent with managers of voluntary adoption firms using their discretion to reduce the option life for new grants and accelerating their vesting period (Balsam et al. 2008).

Dividend yield for voluntary adopters was significantly higher than the yield for control firms across the entire period. High dividend yield reduces stock price which reduces the fair value of options (Grinblatt and Titman 2002; Core and Guay 2002). However, dividend yield does not demonstrate the same pattern as stock price volatility or time-to-maturity. There is no increase in dividend yield corresponding to the issuance of SFAS 123(R). Furthermore, given the importance of dividend policy to investors, it seems unlikely that management is using dividend yield for this purpose. We assume that there are other overriding economic forces determining dividend yield (see Brav et al. 2005; Allen and Michaely 2003).

The risk-free interest rate is an exogenous variable in that it is derived from market forces outside the control of management. So, it is not surprising that interest rate levels do not respond to the issuance of SFAS 123(R). Consistent with our expectations, voluntary adopters are larger firms with generally higher earnings and lower book-to-market ratios. Moreover, the free cash flow variable demonstrates no particular pattern, and the debt-to-assets ratio indicates that early adopters have a higher debt burden than control firms. 
Table 3. Mean Differences by Year for Black-Scholes Model Inputs and Control Variables.

\begin{tabular}{|c|c|c|c|c|c|c|c|c|c|c|c|c|c|c|c|c|c|}
\hline \multirow{2}{*}{$\begin{array}{c}\text { Year } \\
2000\end{array}$} & \multirow{2}{*}{$\begin{array}{c}\text { Category } \\
\text { Early Adopters }\end{array}$} & $\begin{array}{l}\text { Risk Free } \\
\text { Rate (\%) }\end{array}$ & \multicolumn{2}{|c|}{$\begin{array}{c}\text { Stock Price } \\
\text { Volatility } \\
(\%) \\
\end{array}$} & \multicolumn{2}{|c|}{$\begin{array}{l}\text { Time to } \\
\text { Maturity } \\
\text { (Years) }\end{array}$} & \multicolumn{2}{|c|}{$\begin{array}{l}\text { Dividend } \\
\text { Yield (\%) }\end{array}$} & \multicolumn{2}{|c|}{$\begin{array}{c}\text { Size } \\
\text { (\$ millions) }\end{array}$} & \multicolumn{2}{|c|}{$\begin{array}{c}\text { Book to } \\
\text { Market } \\
\text { Ratio } \\
\end{array}$} & \multicolumn{2}{|c|}{$\begin{array}{c}\text { Return } \\
\text { on Assets } \\
\text { Ratio (\%) } \\
\end{array}$} & \multicolumn{2}{|c|}{$\begin{array}{c}\text { Debt to } \\
\text { Assets } \\
\text { Ratio (\%) } \\
\end{array}$} & \multirow{2}{*}{$\begin{array}{c}\begin{array}{c}\text { Financial } \\
\text { Need }\end{array} \\
(0.0064)\end{array}$} \\
\hline & & 5.963 & 39.383 & & 5.894 & & 2.216 & & 17407.980 & & 0.2435 & & $(0.5390)$ & & 27.9131 & & \\
\hline & Controls & 6.006 & 42.930 & & 5.271 & & 0.837 & & 1019.360 & & 1.1132 & & $(2.6482)$ & & 18.7174 & & 0.0129 \\
\hline & t-values & 0.645 & 1.101 & & 3.308 & $* * *$ & 6.135 & $* * *$ & 4.103 & $* * *$ & 2.202 & $* *$ & 0.800 & & 4.103 & $* * *$ & 0.997 \\
\hline \multirow[t]{3}{*}{2001} & Early Adopters & 4.921 & 40.094 & & 5.829 & & 2.119 & & 16558.460 & & 0.5548 & & $(0.9190)$ & & 29.2225 & & 1.3878 \\
\hline & Control & 4.780 & 44.506 & & 5.265 & & 0.798 & & 1493.110 & & 0.7755 & & $(2.4679)$ & & 19.8582 & & $(0.0286)$ \\
\hline & t-value & 1.585 & 1.468 & & 3.056 & $* * *$ & 6.087 & $* * *$ & 4.124 & $* * *$ & 2.734 & $* * *$ & 0.694 & & 4.158 & $* * *$ & 1.016 \\
\hline \multirow[t]{3}{*}{2002} & Early Adopters & 4.064 & 39.745 & & 5.745 & & 2.053 & & 13075.860 & & 0.3780 & & 0.1973 & & 29.3824 & & 1.5270 \\
\hline & Controls & 3.860 & 44.485 & & 5.278 & & 0.829 & & 1540.720 & & $(0.4013)$ & & $(1.5128)$ & & 19.9463 & & 0.0148 \\
\hline & t-values & $2.069^{* *} \quad * *$ & 1.708 & & 2.432 & $* *$ & 5.760 & $* * *$ & 4.405 & $* * *$ & 0.698 & & 0.776 & & 4.049 & $* * *$ & 1.006 \\
\hline \multirow[t]{3}{*}{2003} & Early Adopters & 3.281 & 41.261 & & 5.818 & & 2.083 & & 16069.510 & & 0.3456 & & 1.9747 & & 27.9746 & & (1.1507) \\
\hline & Controls & 3.158 & 44.816 & & 5.727 & & 0.916 & & 1647.060 & & 0.5207 & & 0.3306 & & 20.4524 & & 0.0271 \\
\hline & t-values & 1.412 & 1.139 & & 0.450 & & 5.073 & $* * *$ & 4.734 & $* * *$ & 1.072 & & 0.870 & & 3.158 & $* * *$ & 0.991 \\
\hline \multirow[t]{3}{*}{2004} & Early Adopters & 3.466 & 37.136 & & 5.547 & & 1.856 & & 18276.700 & & 0.4378 & & 3.6704 & & 27.2430 & & $(0.5797)$ \\
\hline & Controls & 3.516 & 45.315 & & 5.797 & & 0.924 & & 2016.820 & & 0.4952 & & $(0.0077)$ & & 22.6405 & & $(0.0012)$ \\
\hline & t-values & 0.687 & 3.552 & $* * *$ & 1.248 & & 4.563 & $* * *$ & 4.776 & $* * *$ & 0.975 & & 2.178 & $* * *$ & 1.618 & & 0.958 \\
\hline \multirow[t]{3}{*}{2005} & Early Adopters & 3.980 & 34.944 & & 5.549 & & 1.864 & & 18787.830 & & 0.4037 & & 0.3168 & & 26.9989 & & 0.8284 \\
\hline & Controls & 3.992 & 43.023 & & 5.678 & & 0.977 & & 2393.360 & & 0.4984 & & 0.2590 & & 22.2430 & & 0.0028 \\
\hline & t-values & 0.231 & 3.676 & $* * *$ & 0.633 & & 4.505 & $* * *$ & 4.949 & $* * *$ & 1.267 & & 0.017 & & 1.849 & $*$ & 1.012 \\
\hline \multirow[t]{3}{*}{2006} & Early Adopters & 4.585 & 32.135 & & 5.460 & & 1.846 & & 21610.640 & & 0.3052 & & 3.6583 & & 26.8481 & & $(0.4585)$ \\
\hline & Controls & 4.558 & 41.308 & & 5.646 & & 0.915 & & 2754.980 & & 0.4945 & & $(1.2651)$ & & 20.2345 & & $(0.0304)$ \\
\hline & t-values & 0.539 & 4.559 & $* * *$ & 0.958 & & 5.123 & $* * *$ & 5.072 & $* * *$ & 1.209 & & 2.102 & $* *$ & 2.642 & $* * *$ & 0.896 \\
\hline \multirow[t]{3}{*}{2007} & Early Adopters & 4.523 & 30.603 & & 5.413 & & 4.750 & & 21185.580 & & 0.3727 & & 0.7355 & & 28.7783 & & $(2.6630)$ \\
\hline & Controls & 4.478 & 41.471 & & 5.187 & & 2.791 & & 3159.810 & & $(7.3301)$ & & $(0.2007)$ & & 22.7937 & & 0.0080 \\
\hline & t-values & 0.909 & 5.553 & $* * *$ & 1.242 & & 0.564 & & 4.683 & $* * *$ & 0.997 & & 0.425 & & 2.031 & $* *$ & 0.680 \\
\hline \multirow[t]{3}{*}{ All Years } & Early Adopters & 4.329 & 36.960 & & 5.657 & & 2.320 & & 17849.660 & & 0.3804 & & 1.1528 & & 28.0316 & & $(0.1171)$ \\
\hline & Controls & 4.289 & 43.513 & & 5.486 & & 1.098 & & 2010.141 & & $(0.4075)$ & & $(0.9298)$ & & 20.8529 & & 0.0003 \\
\hline & t-values & 1.010 & 7.026 & $* * *$ & 2.490 & $* *$ & 3.057 & $* * *$ & 12.934 & $* * *$ & 0.872 & & 2.521 & $* *$ & 8.083 & $* * *$ & 0.210 \\
\hline
\end{tabular}

$*, * *, * * *$ indicates statistical significance at the $0.10,0.05$, or 0.01 level, respectfully. 
Table 4 provides year by year results for equation (1) involving the four disclosed Black-Scholes model inputs. The coefficient for stock price volatility is close to zero before issuance of SFAS 123(R), but becomes consistently negative after that. The coefficient for time-to-maturity is consistently positive before, but becomes negative from $2004-2006$. The coefficient for the risk-free interest rate is not significant and the coefficient for dividend yield is consistently significant throughout the period. These results are consistent with the proposition that management is using its discretion in estimation of stock price volatility and time-to-maturity to reduce the fair value of stock options. 
Table 4. Logistic Regression of Black-Scholes Model Estimated Inputs.

\begin{tabular}{|c|c|c|c|c|c|c|c|c|c|c|c|c|c|c|c|c|c|c|}
\hline \multirow{2}{*}{ Intercept } & \multicolumn{2}{|c|}{ All Years } & \multicolumn{2}{|c|}{2000} & \multicolumn{2}{|c|}{2001} & \multicolumn{2}{|c|}{2002} & \multicolumn{2}{|c|}{2003} & \multicolumn{2}{|c|}{2004} & \multicolumn{2}{|c|}{2005} & \multicolumn{2}{|c|}{2006} & \multicolumn{2}{|c|}{2007} \\
\hline & & & & & & & & & & & & & & & & & & \\
\hline Coefficient & -0.17 & & -0.80 & & -2.03 & & -1.21 & & -0.87 & & 0.72 & & 0.02 & & 0.36 & & 0.58 & \\
\hline Chi-Square & 0.70 & & 0.40 & & 7.61 & $* * *$ & 5.11 & $* *$ & 2.75 & $*$ & 1.33 & & 0.00 & & 0.08 & & 0.20 & \\
\hline \multicolumn{19}{|l|}{ Risk-Free Rate } \\
\hline Coefficient & 0.02 & & -0.12 & & 0.14 & & 0.08 & & 0.13 & & 0.06 & & 0.21 & & 0.09 & & 0.05 & \\
\hline Chi-Square & 0.35 & & 0.44 & & 0.88 & & 0.38 & & 0.97 & & 0.10 & & 0.73 & & 0.12 & & 0.04 & \\
\hline \multicolumn{19}{|l|}{ Stock Price Volatility } \\
\hline Coefficient & -0.01 & & 0.00 & & 0.00 & & 0.00 & & 0.00 & & -0.01 & & -0.02 & & -0.02 & & -0.04 & \\
\hline Chi-Square & 19.57 & $* * *$ & 0.07 & & 0.14 & & 0.00 & & 0.15 & & 5.93 & $* *$ & 6.79 & $* * *$ & 7.51 & $* * *$ & 24.19 & $* * *$ \\
\hline \multicolumn{19}{|l|}{ Time-to-Maturity } \\
\hline Coefficient & 0.03 & & 0.17 & & 0.14 & & 0.08 & & 0.00 & & -0.12 & & -0.11 & & -0.07 & & 0.11 & \\
\hline Chi-Square & 1.70 & & 6.45 & $* *$ & 4.31 & $* *$ & 1.36 & & 0.00 & & 2.82 & $*$ & 2.85 & $*$ & 1.51 & & 2.03 & \\
\hline \multicolumn{19}{|l|}{ Dividend Yield } \\
\hline Coefficient & 0.15 & & 0.35 & & 0.37 & & 0.34 & & 0.28 & & 0.22 & & 0.23 & & 0.25 & & 0.00 & \\
\hline Chi-Square & 48.53 & $* * *$ & 24.41 & $* * *$ & 23.23 & $* * *$ & 20.91 & $* * *$ & 18.79 & $* * *$ & 11.59 & $* * *$ & 12.36 & $* * *$ & 11.17 & $* * *$ & 0.51 & \\
\hline \multicolumn{19}{|l|}{ Model: } \\
\hline Observations (n) & 2909.00 & & 359.00 & & 363.00 & & 371.00 & & 372.00 & & 372.00 & & 371.00 & & 371.00 & & 330.00 & \\
\hline Likelihood Ratio & 110.19 & $* * *$ & 46.62 & $* * *$ & 45.34 & $* * *$ & 38.15 & $* * *$ & 28.16 & $* * *$ & 30.12 & $* * *$ & 29.92 & $* * *$ & 36.92 & $* * *$ & 33.89 & $* * *$ \\
\hline Wald & 98.47 & $* * *$ & 33.20 & $* * *$ & 31.71 & $* * *$ & 28.52 & $* * *$ & 21.43 & $* * *$ & 25.21 & $* * *$ & 25.12 & $* * *$ & 30.11 & $* * *$ & 26.38 & $* * *$ \\
\hline
\end{tabular}

$*, * *, * * *$ indicates statistical significance of chi-squares at the $10 \%, 5 \%$, and $1 \%$ level, respectfully.

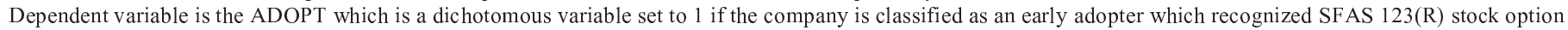
expense in the period 2002-2004, 0 otherwise. 
Taken together, Tables 3 and 4 provide some evidence for rejecting $\mathrm{Ho}_{2}$. The evidence supports the conclusion that managers might be engaged in some preemption behavior by using their discretion to reduce the fair value of stock options and preempt the effects of recognizing stock option expense under SFAS 123(R). Furthermore, it appears that stock price volatility and time-to-maturity are the estimated pricing model inputs that are more useful for this purpose. Consistent with Bartov et al. (2007), stock price volatility appears to have the greater impact on the fair value of stock options. These findings are also consistent with Johnston (2006) who found that managers used their discretion to reduce the SFAS 123(R) stock option expense in 2002, but inconsistent with Hodder et al. (2006).

However, we fail to reject $\mathrm{Ho}_{1}$. Consistent with Balsam et al. (2003), there is no evidence suggesting that managers use their discretion over the Black-Scholes model inputs to reduce the disclosed pro forma stock option expense. During the period of 2000 - 2003, Tables 3 and 4 demonstrate that the stock price volatility of voluntary adopters and control firms were not significantly different. During this same period, Table 3 shows the time-to-maturity was significantly longer for voluntary adopters, which is consistent with disclosing higher fair values and larger pro forma stock option expense under SFAS 123. These findings are inconsistent with Aboody et al. (2006) who find that managers understate the pro forma stock option expense. However, they compare disclosed option fair values to benchmark values. We look only at the option pricing model input values disclosed by management and how these estimates change over time.

Table 5 summarizes the logistic regression analysis of equation (2). The decision to adopt SFAS 123(R) is characterized for voluntary adopters and their pair matched controls for the year of the adoption. A stepwise backwards elimination was used to reduce the full model (model 1 in Table 5) to the final parsimonious model (model 6 in Table 5). The final model (significant at the 0.01 level) was able to correctly identify voluntary adopters or control firms $75.9 \%$ of the time. 
However, the purpose for this analysis is to determine whether political costs or other firm attributes characterize the voluntary adoption decision. The final model (in equation 3 below) describes those variables most closely associated with the voluntary adoption decision.

$$
\text { Adopt }=-4.0529+0.2228 R F+0.00871 V O L+0.2779 D I V+0.3757 \text { Size }
$$

The risk-free rate of interest, stock price volatility, dividend yield, and size remain in the final model. In 2003 when 80 percent of the early adoptions took place, the risk-free rate was favorable for the decision in that it had dropped from higher levels in earlier years. The stock price volatility for voluntary adopters was at its peak providing managers with the opportunity to preempt or minimize the effects of this accounting change. The risk-free rate and stock price volatility are both positive but not significant in the model. 
Table 5. Prediction Model for Voluntary Adoption of SFAS 123(R) Stock Option Expense

\begin{tabular}{|c|c|c|c|c|c|c|}
\hline & Model 1 & Model 2 & Model 3 & Model 4 & Model 5 & Model 6 \\
\hline \multicolumn{7}{|l|}{ Intercept } \\
\hline Coefficient & -4.9868 & -4.9332 & -4.7491 & -4.2950 & -4.3010 & -4.0529 \\
\hline Chi-Square & $20.8566 * * *$ & $23.2807 * * *$ & $30.5033 * * *$ & $27.4828 * * *$ & $27.6985 * * *$ & $27.1907 * * *$ \\
\hline \multicolumn{7}{|l|}{ Risk Free Rate } \\
\hline Coefficient & 0.3137 & 0.3199 & 0.2657 & 0.2318 & 0.2237 & 0.2228 \\
\hline Chi-Square & $3.6903 *$ & $4.1427 * *$ & $3.4051 *$ & $2.7455^{*}$ & 2.6034 & 2.5984 \\
\hline \multicolumn{7}{|l|}{ Volatility } \\
\hline Coefficient & 0.0137 & 0.0135 & 0.0094 & 0.0095 & 0.0089 & 0.00871 \\
\hline Chi-Square & $5.5492 * *$ & $5.7301 * *$ & $3.3908^{*}$ & $3.7588 *$ & $3.4659 *$ & 3.5081 \\
\hline \multicolumn{7}{|l|}{ Time to Maturity } \\
\hline Coefficient & 0.0109 & & & & & \\
\hline Chi-Square & 0.0192 & & & & & \\
\hline \multicolumn{7}{|l|}{ Dividend Yield } \\
\hline Coefficient & 0.2740 & 0.2738 & 0.2627 & 0.2791 & 0.2788 & 0.2779 \\
\hline Chi-Square & $11.9193 * * *$ & $11.8963 * * *$ & $11.3783 * * *$ & $14.2611 * * *$ & $14.2090 * * *$ & $14.3005 * * *$ \\
\hline \multicolumn{7}{|l|}{ Size } \\
\hline Coefficient & 0.3818 & 0.3807 & 0.3487 & 0.3795 & 0.3877 & 0.3757 \\
\hline Chi-Square & $21.8638 * * *$ & $21.9534 * * *$ & $30.6327 * * *$ & $30.2160 * * *$ & $32.4700 * * *$ & $31.5178 * * *$ \\
\hline \multicolumn{7}{|l|}{ Book to Market } \\
\hline Coefficient & 0.3724 & 0.3781 & 0.3935 & 0.2720 & 0.2925 & \\
\hline Chi-Square & 1.3147 & 1.3806 & 1.8419 & 0.9214 & 1.0917 & \\
\hline \multicolumn{7}{|l|}{ Debt to Assets } \\
\hline Coefficient & 0.0022 & 0.00218 & 0.0106 & & & \\
\hline Chi-Square & 0.1143 & 0.1138 & $3.3723^{*}$ & & & \\
\hline \multicolumn{7}{|l|}{ Return on Assets } \\
\hline Coefficient & 0.0090 & 0.0090 & 0.0058 & 0.0047 & & \\
\hline Chi-Square & 0.8662 & 0.8572 & 0.5152 & 0.3784 & & \\
\hline \multicolumn{7}{|l|}{ Financial Need } \\
\hline Coefficient & -0.3060 & -0.2917 & & & & \\
\hline Chi-Square & 0.1195 & 0.1102 & & & & \\
\hline \multicolumn{7}{|l|}{ Model: } \\
\hline Likelihood Ratio & $64.2498 * * *$ & $64.2307 * * *$ & $83.7727 * * *$ & $78.2654 * * *$ & $77.8574 * * *$ & $76.7458 * * *$ \\
\hline Classification $\%$ & $75.9 \%$ & $76.0 \%$ & $77.1 \%$ & $75.7 \%$ & $75.5 \%$ & $75.9 \%$ \\
\hline
\end{tabular}

$*, * *, * * *$ indicates statistical significance of chi-squares at the $10 \%, 5 \%$, and $1 \%$ level, respectfully.

Dependent variable is the ADOPT which is a dichotomous variable set to 1 if the company is classified as an early adopter which recognized SFAS 123(R) stock option expense in the period 2002-2004, 0 otherwise.

The decision to adopt SFAS 123(R) voluntarily seems to have been primarily a political decision. Dashmukh et al. (2006) asserted that voluntary adoption of SFAS123(R) was essentially a political act. Given the political climate after Enron and the Sarbanes-Oxley Act, they argued that it was politically advantageous for a company to be seen as having higher quality corporate governance and more transparent financial statements. Holthausen and Leftwich (1983) argued that political cost could be captured using two variables: size and leverage. Size is a proxy for political visibility while leverage is a proxy for contracting and monitoring costs. Watts and Zimmerman (1978) provide an alternative interpretation for political costs where large firms tended to be 
voluntary adopters of income decreasing accounting changes because they have the capacity to absorb the impact of the new regulation without impairing the future prospects of the firm.

While Aboody et al. (2004) found voluntary adopters of SFAS 123(R) to be larger firms, they did not distinguish between the two views of political costs. Dechow et al. (1996) examined the respondents to the Standard's Exposure Draft and found those firms actively participating in the process were not the larger firms. This suggests size may not be the best proxy for political visibility with the early adoption of SFAS 123(R).

The results in Table 5 indicate that voluntary adopters are systematically larger firms with higher dividend yields than control firms. While the debt to assets ratio is significantly larger for voluntary adopters in 2003 (Table 3), it appears not to play a significant role in the adoption decision. The voluntary adopters are also characterized as having higher return on assets and lower book to market ratios in 2003 (Table 3). Taken together, these results favor the Watts and Zimmerman (1978) interpretation of political costs. The voluntary adopters in this study seem to have been better able to absorb the income decreasing effects of this accounting change than the control firms. This is consistent with Sami and Welsh (1992) who found that voluntary adopters of SFAS 87 were larger firms with more fully funded pension obligations.

\section{CONCLUSION}

Companies may use accounting choices for sending a signal to the market. Companies adopting income reducing accounting rules voluntarily are perceived to be sending a reliable signal due to the compliance costs. Voluntary adoption of SFAS 123(R) may have signaled good corporate governance and higher transparency of financial statements for adopting firms, but they have also incurred the compliance costs associated with this signal.

This research examined the period before and after voluntary adoption of SFAS 123(R) for evidence of preemption to mitigate its effect through the mandatory adoption period. During the periods of disclosure of 
pro forma stock option expense under SFAS 123, there is no evidence of using the option pricing model inputs to manage options fair value and related disclosed compensation expense. After adoption of SFAS 123(R), the evidence supports the proposition that managers are preemptively using their discretion to decrease estimated fair value of stock options by reducing two of the option pricing model inputs on which management has more discretion. The reduction of stock price volatility and time-to-maturity allowed managers to reduce the recognized compensation expense.

Consistent with Watts and Zimmerman (1978) interpretation of political costs, the voluntary adopters of SFAS 123(R) were larger firms with higher dividend yield than control firms. These firms should be better able to absorb this income decreasing accounting change. Furthermore, the documented use of management's discretion would facilitate the process by preempting the income reducing effects of the adoption and increasing the likelihood that voluntary adopters would be able to absorb the adverse effects of this accounting change.

The results of this paper should have important implications for both accounting regulators, practitioners, and other financial statement users. Accounting regulators need to be thoughtful when they set the effective dates of their new accounting pronouncements. On one hand, they need to allow prepares and practitioners enough time to adapt to any new requirements. On the other hand, long transition periods before the effective dates might induce preparers to design or enter into some new contractual arrangements that might undo the intended goals behind issuing the new standard in terms of improving recognition and disclosure of some economic circumstances in the firm. This will be especially true for accounting areas where management discretion and intention play a significant role in financial reporting. Results of the paper have also implications for accounting regulators when considering the economic consequences of their accounting pronouncements and deciding whether or not to allow early adoption of the newly-issued pronouncement before its mandatory effective date. Results should also have some implications for financial analysts and users of financial statements to recognize that the early voluntary adoption of new accounting pronouncements should not be always perceived as a signal 
of better or superior financial reporting quality. Early and voluntary adoption of new accounting pronouncements might just be a mechanism used to alleviate or smooth out their ultimate effects on financial statements before the announced official effective date when users of financial statements start to closely monitor and discount the effects of the newly-mandated accounting rules and compare their effects on different companies. 


\section{REFERENCES}

Aboody, D., and Kasznik, R. (2000), CEO stock option awards and the timing of corporate voluntary disclosures, Journal of Accounting and Economics 29 (1), pp. 73-100.

Aboody, D., Barth, M., and Kasznik, R., (2004), Firms voluntary recognition of stock-based compensation expense, Journal of Accounting Research 42 (2), pp. 123-150.

Aboody, D., Barth, M., and Kasznik, R., (2006), Do firms manage stock-based compensation expense disclosed under SFAS 123?, Review of Accounting Studies 11(4), pp. 429-461.

Ahmed, A., Kilic, E., and Lobo, G., (2006), Does recognition versus disclosure matter? Evidence from valuerelevance of banks' recognized and disclosed derivative financial instruments, Accounting Review 81(3), pp. 567-588.

Allen, F., and Michaely, R., (2003), Payout policy, In Handbook of Economics of Finance. Volume 1A: Corporate Finance, edited by G. M. Constantinidies, M. Harris, and R. E. Stulz, Amsterdam: Elsevier.

Amir, E., and Ziv, A., (1997a), Economic consequences of alternative adoption rules of new accounting standards, Contemporary Accounting Research 14(3), pp. 543-568.

Amir, E., and Ziv, A., (1997b), Recognition, disclosure, or delay: Timing the adoption of SFAS

No. 106, Journal of Accounting Research 35(1), pp. 61-81.

Amir, E., and Livnat, J., (1996), Multiperiod analysis of adoption motives: The case of SFAS No. 106, Accounting Review 71(4), pp. 539-553.

Balsam, S., Mozes, H., and Newman, H., (2003), Managing pro forma stock option expense under SFAS No. 123, Accounting Horizons 17(1), pp. 31-45.

Balsam, S., Haw, I., and Lilien, S., (1995), Mandated accounting changes and managerial discretion, Journal of Accounting and Economics 20, pp. 3-29.

Balsam, S., Reitenga, A., and Yin, J., (2008), Option acceleration in response to SFAS No. 123(R), Accounting Horizons 22(1), pp. 23-45.

Bartov, E., Mohanram, P., and Nissim, D., (2007), Managerial discretion and the economic determinants of the disclosed volatility parameter for valuing ESOs, Review of Accounting Studies 12(1), pp. 155-179.

Botosan, C., and Plumlee, M., (2001), Stock option expense: The sword of Damocles revealed, Accounting Horizons 15(4), pp. 311-327.

Brav, A., Graham, J., Harvey, C., and Michaely, R., (2005), Payout policy in the $21^{\text {st }}$ century, Journal of Financial Economics 77, pp. 483-527.

Chauvin, K., and Shenoy, C., (2001), Stock price decreases prior to executive stock option grants, Journal of Corporate Finance 7(1), pp. 53-76.

Cohen, D., Dey, A., and Lys, T., (2008), Real and accrual-based earnings management in the pre- and postSarbanes-Oxley period, Accounting Review 83(3), pp. 757-787.

Coller, M., and Higgs, J., (1997), Firm valuation and accounting for employee stock options, Financial Analyst Journal 53(1), pp. 26-34.

Core, J., and Guay, W., (2002), Estimating the value of employee options portfolios and their sensitivities to price and volatility, Journal of Accounting Research 49(3), pp. 613-630.

Davis-Friday, P., Liu, C., and Mittelstaedt, H., (2004), Recognition and disclosure reliability: evidence from SFAS 106, Contemporary Accounting Research 21(2), pp. 399-430. 
Dechow, P., Hutton, A., and Sloan, R., (1996), Economic consequences of accounting for stock based compensation, Journal of Accounting Research 34(Supplement), pp. 1-20.

Deshmukh, S., Howe, K., and Luft, C., (2006), Executive stock options: To expense or not?, Financial Management 35(1), pp. 87-106.

Espahbodi, H., Espahbodi, P., Rezaee, Z., and Tehranian, H., (2002), Stock price reaction and value relevance of recognition versus disclosure: The case of stock-based compensation, Journal of Accounting and Economics 33, pp. 343-373.

Frederickson, J., Hodge, F., and Pratt, J., (2006), The evolution of stock option accounting: Disclosure, voluntary recognition, mandated recognition, and management disavowals, Accounting Review 81(5), pp.1073-1093.

Grinblatt, M., and Titman, S., (2002), Financial markets and corporate strategy, $2^{\text {nd }}$ edition, New York: McGraw-Hill.

Gujarathi, M., and Hoskin, R., (1992), Evidence of earnings management by the early adopters of SFAS 96, Accounting Horizons 6(4), pp. 18-31.

Gul, F., (2001), Free cash flow, debt-monitoring and managers' LIFO/FIFO policy choice, Journal of Corporate Finance, 7 (4), pp. 475-92.

Hirst, E., et al., (2005), Response to the FASB's exposure draft on share-based payment: An amendment of FASB statements No. 123 and No. 95, Accounting Horizons 19(2), pp. 101-114.

Hodder, L., Mayew, W., McAnally, M., and Weaver, C., (2006), Employee stock option fair-value estimates: Do managerial decisions and incentives explain accuracy?, Contemporary Accounting Research 23(4), pp. 933-75.

Holthausen, R., and Leftwich, R., (1983), The economic consequences of accounting choice: Implications of costly contracting and monitoring, Journal of Accounting and Economics 5, pp. 77-117.

Jeter, D., Chaney, P., and Daley, M., (2008), Joint accounting choices: An examination of firms adoption strategies for SFAS no. 106 AND SFAS no. 109, Review of Quantitative Finance and Accounting, 30(2), pp. 153-153.

Johnston, D., (2006), Managing stock option expense: The manipulation of option-pricing model assumptions, Contemporary Accounting Research 23(2), pp. 395-425.

Jones, S., (2011), Does the capitalization of intangible assets increase the predictability of corporate failure?, Accounting Horizons, 25(1), pp. 41-70.

Krishnan, G., Srinidhi, B., and Su, L., (2008), Inventory policy, accruals quality and information risk, Review of Accounting Studies, 13(2-3), pp. 369-410.

Langer, R., and Lev, B., (1993), The FASB's policy of extended adoption for new standards: An examination of FAS No. 87, Accounting Review 68(3), pp. 515-533.

Lie, E., (2001), Detecting abnormal operating performance: Revisited, Financial Management, 30(2), pp. 7791.

Lie, E., (2005), On the timing of CEO stock option awards, Management Science 51(5), pp. 802-812.

Niu, F., and Xu, B., (2009), Does recognition versus disclosure really matter? evidence from the market valuation of recognition of employee stock option expenses, Asia - Pacific Journal of Accounting \& Economics : APJAE, 16(2), pp. 215-234. 
Robinson, D, and Burton, D., (2004), Discretion in financial reporting: The voluntary adoption of fair value accounting for employee stock options, Accounting Horizons 18(2), pp. 97-108.

Sami, H., and Welsh, M., (1992), Characteristics of early and late adopters of pension accounting standard SFAS No. 87, Contemporary Accounting Research 9(1), pp. 212-236.

Schroeder, R., and Schauer, D., (2008), SFAS no. 123R: The controversy and its economic consequences, Managerial Auditing Journal, 23(3), pp. 295-306.

Simon, D., and Costigan, M., (1996), Additional evidence on the determinants of accounting policy choice: The case of positive early adopters of SFAS 96, Quarterly Journal of Business and Economics 35(6), pp. 49-63.

Tung, S., and Weygandt, J., (1994), The determinants of timing in the adoption of new accounting standards: A study of SFAS No. 87, Employers' Accounting for Pensions, Journal of Accounting, Auditing, and Finance 9(2), pp. 325-337.

Viger, C., Belzile, R., and Anandarajan, A., (2008), Disclosure versus recognition of stock option compensation: Effect on the credit decisions of loan officers, Behavioral Research in Accounting 20(1), pp. 93-113.

Watts, R., and Zimmerman, J., (1978), Towards a Positive Theory of the Determination of Accounting Standards, Accounting Review 53(1), pp. 112-134.

Yermack, D., (1997), Good timing: CEO stock option awards and company news announcements, Journal of Finance 52(2), pp. 449-476. 